\title{
Neuroprotective effects of taurine on SH-SY5Y cells under hydrocortisone induced
}

\section{stress}

Efeitos neuroprotetores da taurina em células SH-SY5Y sob estresse induzidlo por hidrocortisona

Efectos neuroprotectivos de la taurina en células SH-SY5Y bajo estrés por hidrocortisona

Received: 07/19/2021 | Reviewed: 07/25/2021 | Accept: 07/26/2021 | Published: 08/03/2021

\author{
Rafaella Carvalho Rossato \\ ORCID: https://orcid.org/0000-0002-4528-0777 \\ Universidade do Vale do Paraíba, Brazil \\ E-mail: rafaella.rossato@hotmail.com \\ Alessandro Eustaquio Campos Granato \\ ORCID: https://orcid.org/0000-0002-5831-9239 \\ Universidade de São Paulo, Brazil \\ E-mail: alessandroecgranato@gmail.com \\ Carlos Dailton Guedes de Oliveira Moraes \\ ORCID: https://orcid.org/0000-0002-0020-1019 \\ Universidade do Vale do Paraíba, Brazil \\ E-mail: carlosdailtongom@gmail.com \\ Geisa Nogueira Salles \\ ORCID: https://orcid.org/0000-0003-4336-1634 \\ Universidade do Vale do Paraíba, Brazil \\ E-mail: geisa.n.salles@gmail.com \\ Cristina Pacheco Soares \\ ORCID: https://orcid.org/0000-0002-0572-074X \\ Universidade do Vale do Paraíba, Brazil \\ E-mail: cpsoares@univap.br
}

\begin{abstract}
Alzheimer's disease (AD) is the most common, progressive and irreversible neurodegenerative disorder, characterized by memory loss, cognitive impairment and behavioral abnormalities. Although there is no cure, several study strategies seek to elucidate mechanisms of the disease. Recent studies address the benefits of taurine. Thus, the present study aims to analyze neuroprotective effects of taurine in human neuroblastoma (SH-SY5Y), using an in vitro experimental model of oxidative stress induced by hydrocortisone. This work showed for the first time that taurine can promote neuroprotection in SH-SY5Y under oxidative stress caused by hydrocortisone. Cell viability was evaluated using crystal violet and the evaluation of cell morphology was performed by scanning electron microscopy (SEM). The viability of SH-SY5Y pre-treated with taurine and stressed with hydrocortisone was preserved, compared to the stressed only group, which was also morphologically observed. Therefore, taurine can represent a considerable therapeutic candidate in the prevention of neurodegenerative diseases, such as AD.
\end{abstract}

Keywords: Alzheimer disease; Oxidative stress; Neuroprotection; Hydrocortisone.

\section{Resumo}

A doença de Alzheimer (DA) é o distúrbio neurodegenerativo mais comum, progressivo e irreversível, caracterizado por perda de memória, prejuízo cognitivo e anormalidades comportamentais. Embora não haja cura, várias estratégias de estudo buscam elucidar os mecanismos da doença. Estudos recentes abordam os benefícios da taurina. Assim, o presente estudo tem como objetivo analisar o efeito neuroprotetor da taurina em neuroblastoma humano (SH-SY5Y), utilizando um modelo experimental in vitro de estresse oxidativo induzido por hidrocortisona. Este trabalho mostrou pela primeira vez que a taurina pode promover a neuroproteção nas células SH-SY5Y sob o estresse oxidativo causado pela hidrocortisona. A viabilidade celular foi avaliada utilizando cristal violeta e a avaliação da morfologia celular foi realizada por microscopia eletrônica de varredura (MEV). A viabilidade das células SH-SY5Y pré-tratadas com taurina e estressadas com hidrocortisona foi preservada, em comparação com o grupo exposto apenas à hidrocortisona, o que foi também observado morfologicamente. Portanto, a taurina pode representar um importante candidato terapêutico na prevenção de doenças neurodegenerativas, como a DA.

Palavras-chave: Doença de Alzheimer; Estresse oxidativo; Neuroproteção; Hidrocortisona.

\section{Resumen}

La enfermedad de Alzheimer (EA) es el trastorno neurodegenerativo más común, progresivo e irreversible, caracterizado por pérdida de memoria, deterioro cognitivo y alteraciones del comportamiento. Aunque no existe cura, varias estrategias de estudio buscan dilucidar los mecanismos de la enfermedad. Estudios recientes abordan los 
beneficios de la taurina. Así, el presente estudio tiene como objetivo analizar el efecto neuroprotector de la taurina en el neuroblastoma humano (SH-SY5Y), utilizando un modelo experimental in vitro de estrés oxidativo inducido por hidrocortisona. Este trabajo demostró por primera vez que la taurina puede promover la neuroprotección en las células SH-SY5Y bajo el estrés oxidativo causado por la hidrocortisona. La viabilidad celular se evaluó utilizando cristal violeta y la evaluación de la morfología celular se realizó mediante microscopía electrónica de barrido (MEB). Se conservó la viabilidad de las células SH-SY5Y pretratadas con taurina y estresadas con hidrocortisona, en comparación con el grupo expuesto solo a hidrocortisona, que también se observó morfológicamente. Por tanto, la taurina puede representar un importante candidato terapéutico en la prevención de enfermedades neurodegenerativas como la EA.

Palabras clave: Enfermedad de Alzheimer; Estrés oxidativo; Neuroprotección; Hidrocortisona.

\section{Graphical abstract}

Figure 1. Representative schematic demonstrating the neuroprotective effect of taurine.

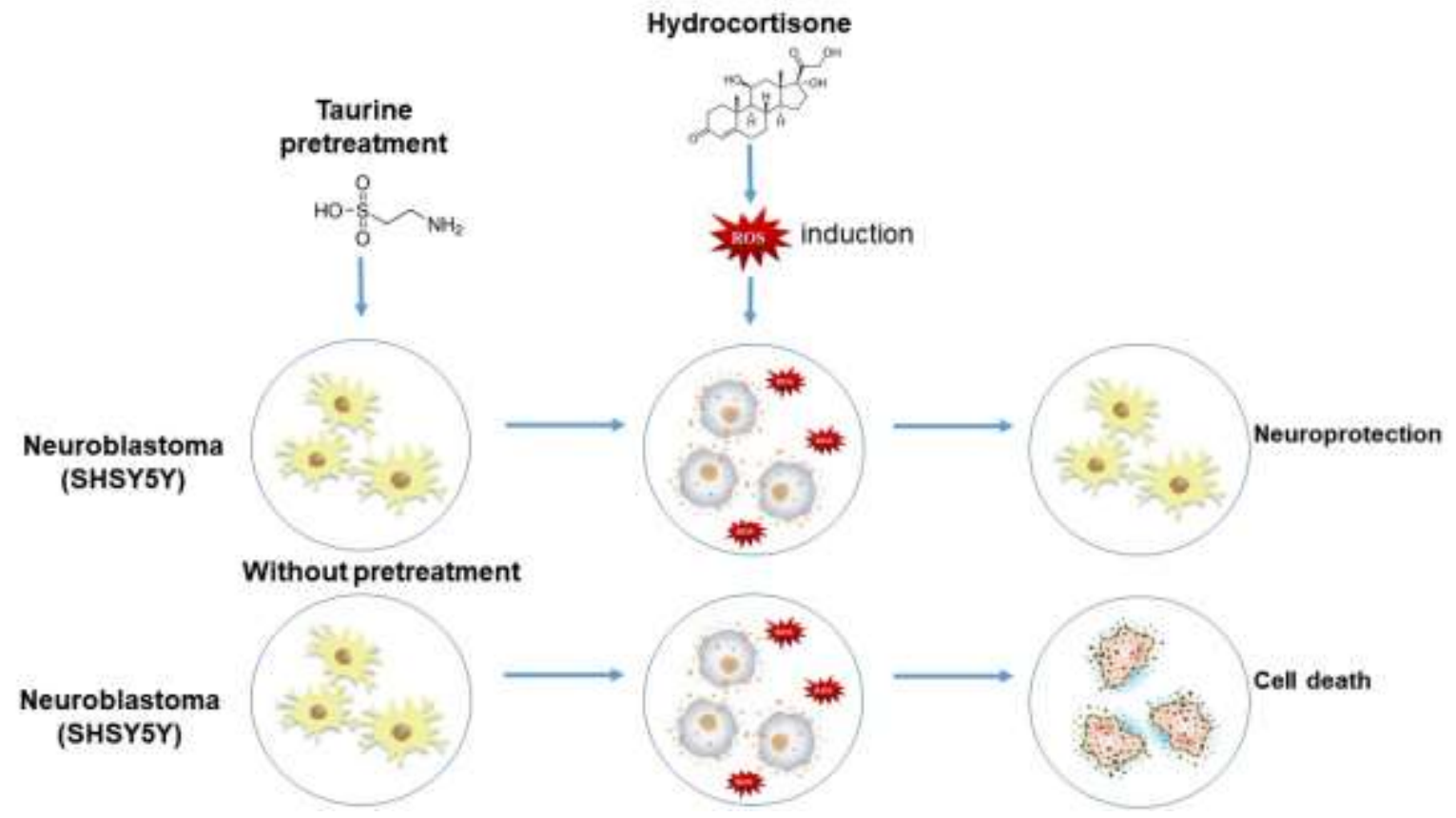

Source: Authors.

\section{Introduction}

Alzheimer's disease (AD) is the most common, progressive, and irreversible neurodegenerative disorder, characterized by memory loss, cognitive impairment, and behavioral abnormalities (Reitz \& Mayeux, 2014) (De Falco et al., 2016). The main risk factors are advanced age and family history; however, studies report that specific genetic mutations correlate with increased susceptibility, as well as the anticipation of clinical signs characteristic of AD (Liu et al., 2013) (Reitz \& Mayeux, 2014). AD's origin is still unknown, but some brain changes are described, including the abnormal production and deposit of $\beta$-amyloid protein and neurofibrillary tangles, resulted from TAU protein hyperphosphorylation (Belyaev et al., 2010).

The reduction in the number of nerve cells (neurons) and the connections between them (synapses) and other critical changes in the AD phenotype should be highlighted. Another point that can be studied is the degree of cognitive damage related to the dysfunction and specific degeneration of cholinergic neurons located in the basal forebrain's cholinergic complex (Barbosa, 2020). It is worth studying the cholinergic receptors that may represent one of the critical events in the pathology of this disease (Grothe et al., 2014). As a consequence of the disease progression, there is a vast loss of neural prolongations, which leads to cerebral atrophy, decreases the weight of the brain mass, in addition to causing impairment in brain metabolism and regeneration 
capacity (Nelson et al., 2012).

In addition to genetic and biochemical changes, another probable reason for neural damage comes from oxidative stress obtained through the formation of reactive oxygen species (ROSs). They are unstable and extremely reactive molecules capable of altering other biomolecules such as proteins, carbohydrates, lipids, and nucleic acids. ROS are usually produced by body metabolism, but when they are produced in excess, they can exceed the cellular capacity for defense and repair, which leads to damage to neural cells (Moraes et al., 2019). It is evident that the chronic stress suffered by neural cells, associated with old age, predisposes to AD's development. Psychological, behavioral, economic, and social risk factors can also be important as protagonists involved in cognitive decline and dementia (Vitaliano et al., 2011). These impairments in executive functions (attention and processing speed) and declarative memory, which is explicit memory evoked in the form of consciousness) are early clinical phenotypes for AD. The brain structures most sensitive to stress are the prefrontal cortex (PFC) and the hippocampus, and they are intricately linked to cognitive domains (Shansky, Lipps; 2013). Those regions contain an exceptionally high density of receptors sensitive to cortisol, a hormone that is usually altered in acute and chronic stress (Márcio Silveira Corrêa et al., 2016).

Hydrocortisone, a drug analogous to the hormone cortisol, can generate ROS, especially in high concentrations, damaging important biomolecules (Rossato et al, 2019). Neural cell's normal functioning can be compromised when these damages are not repaired. Because of this, it provides cellular stress, which can evolve into atypical cells. Finally, the resolution of this process can lead, on the one hand, to cell death when this stress is not corrected; on the other hand, the neural cell survives; however, it becomes senescent and dysfunctional (Mcewen, 2013) (Salles et al., 2018). It is also possible to relate the changes in cortisol levels and ROSs with the decrease in brain-derived neurotrophic factor (BDNF), which modulate synaptic plasticity neurogenesis as neuronal help survival (Jeanneteau \& Chao, 2013).

Counteracting chronic and oxidative stress is necessary. Taurine, or 2-aminoethanesulfonic acid, can be highlighted as promising for this function. Described as an agent capable of neuroprotection, it acts in functions of regulation of brain volume and maintains the integrity of the neural membrane and calcium homeostasis control. Thus, taurine can prevent the neural cell's death since it can reduce oxidative stress (Zhou et al., 2012) (Kilb \& Fukuda, 2017). Taurine is found in abundance in liver and brain, being synthesized from the metabolism of sulfur amino acids (methionine and cysteine), and is also considered a nonessential amino acid (Marcinkiewicz \& Kontny, 2014).

Therefore, the present study seeks to evaluate the effects of taurine in stress conditions provided by hydrocortisone in neural cells to simulate the metabolic and oxidative stress, characteristic of AD. Thus, cells were pretreated with taurine, and later stressed with hydrocortisone, in order to study the neuroprotective mechanisms of taurine as a possible retarding and preventive agent for $\mathrm{AD}$.

\section{Methodology}

\section{Description of the methodology used}

In this work, quantitative and qualitative studies were performed. The methodology described in this article was enough to reach and respond to the objectives outlined at the beginning of the work. Our databases were all obtained primarily, that is, by the authors of the work. All our experimentally collected data were obtained in a recent period (2019 to 2021). We used the most recent bibliographic references possible to prepare the introduction and discussion of this work, which are all available in "Google Scholar". For the quantitative results, statistical analyses was performed using the software GraphPad Prism 6.0. For the analysis of qualitative data, "ImageJ" software was used. All methodologies described here can be replicated by other researchers. 


\section{Cell culture}

SH-SY5Y cells (Human Neuroblastoma ATCC - CRL-2266) were cultivated in $25 \mathrm{~cm}^{2}$ cell culture flasks, at $37{ }^{\circ} \mathrm{C}$ under 5 \% CO2 in DMEM/F12 (Gibco - Dulbecco's Modified Eagle Medium - Nutrient Mixture) supplemented with $10 \%$ fetal bovine serum (Life Technologies) and $1 \%$ antibiotic and antimycotic (penicillin and streptomycin - Thermo Fisher Scientific, Invitrogen) (Salles et al., 2018).

\section{Cell plating}

Cells were cultivated in 96-well plates, with a cellular density of 1 x 104 cell/well for cell viability assay. For the analysis of cell morphology, SH-SY5Y cells were plated in 24-well plates on coverslips with a cellular density of 1 x 105 cell/well (Salles et al., 2018).

\section{Experimental groups}

The groups were described below according to the treatment the cells received.

-Control group: cells not exposed to taurine or hydrocortisone.

-Taurine only group: cells exposed to taurine.

-Hydrocortisone only group: cells exposed to hydrocortisone stressor agent.

-Taurine and hydrocortisone group: cells pretreated with taurine followed by hydrocortisone exposure.

\section{Pretreatment}

SH-SY5Y cells were pretreated with taurine (Sigma) $(0.5 \mathrm{mg} / \mathrm{mL})$ in DMEM/F12 (Gibco - Dulbecco's Modified Eagle Medium - Nutrient Mixture) supplemented with $10 \%$ fetal bovine serum (Life Technologies) and $1 \%$ antibiotic and antimycotic (penicillin and streptomycin - Thermo Fisher Scientific, Invitrogen) (Rossato et al, 2019).

\section{Oxidative stress induction}

SH-SY5Y cells were subjected to $200 \mu \mathrm{M}$ hydrocortisone (Teuto) as stressor agent, dissolved in DMEM/F12 (Gibco Dulbecco's Modified Eagle Medium - Nutrient Mixture), supplemented with $10 \%$ fetal bovine serum (Life Technologies) and $1 \%$ antibiotic and antimycotic (penicillin and streptomycin - Thermo Fisher Scientific, Invitrogen) (Rossato et al, 2019).

\section{Cell viability assay}

Cell viability assay evaluates the cytotoxicity of the compound employing a colorimetric test. The method consists of verifying the cell density by staining the DNA, obtaining quantitative information on the relative density of live cells adhered to culture plates, that is, obtaining indirectly the amount of DNA in the samples and consequently the number of cells present in the analyzed groups (Moraes et al., 2019).

Cells were washed with phosphate buffer saline (PBS) and incubated with $100 \mu \mathrm{L}$ crystal violet solution (5\%) for 4 min, at room temperature, protected from light. Cells were then washed with running water to remove excess dye and incubated with Dimethyl sulfoxide (DMSO) for $1 \mathrm{~h}$. Then, a SpectraCount - Packard $570 \mathrm{~nm}$ spectrophotometer reader was used to evaluate the results. The whole process was carried out in the dark. Data collected were statistically analyzed (Moraes et al., 2019).

\section{Cell morphology analysis}

Cells were washed three times with $0.1 \mathrm{M}$ cacodylate buffer, fixed with glutaraldehyde $2.5 \%$ and paraformaldehyde $4 \%$ in $0.1 \mathrm{M}$ cacodylate buffer for one hour. Then, cells were dehydrated in a series of acetone concentrations $(30 \%, 50 \%, 70 \%, 90 \%$ 
and 100\%, respectively) for 10 minutes each (Salles et al., 2017) (Salles et al., 2018). Cells were incubated in acetone 100\% + Hexamethyldisilazane (HMDS) (1:1) and in 100\% HMDS, for 10 minutes each. The final material was metalized in EMITECH $\mathrm{K} 550 \mathrm{X} \circledast$ (4 minutes and 50 seconds in a vacuum cycle using $17 \mathrm{kV}$ ), covering a thin layer of gold on the samples. Cellular morphology was assessed by the Scanning Electron Microscope EVO MA10-Zeiss®. The frequency of membrane projections in the neural cell line SH-SY5Y was counted with the micrographs obtained by SEM, using ImageJ software.

\section{Statistical analysis}

The present study was carried out with $\mathrm{n}=8$ and repeated three times separately to confirm the obtained results. Statistical significance was admitted with $\mathrm{p}<0.05$. GraphPad Prism 6® software was used, and the statistical tests used were the ANOVA ONE-WAY and the Tukey test.

\section{Results}

\section{Cell viability assay}

As observed in Figure 2, cells exposed to $1 \mathrm{mg} / \mathrm{mL}$ of taurine were as viable as the control group (no statistical difference between them). In contrast, the concentration of $0.25 \mathrm{mg} / \mathrm{mL}$ statistically decreased cell viability (p <0.0001) compared to the control group (a). On the other hand, $0.5 \mathrm{mg} / \mathrm{mL}$ of taurine significantly increased cell viability $(\mathrm{p}=0.0457)$, compared to control group (b) (Figure 2).

Figure 2. SH-SY5Y viability on different concentrations of taurine $(0.25 ; 0.5$ and $1 \mathrm{mg} / \mathrm{mL}$, respectively) compared to the control group.

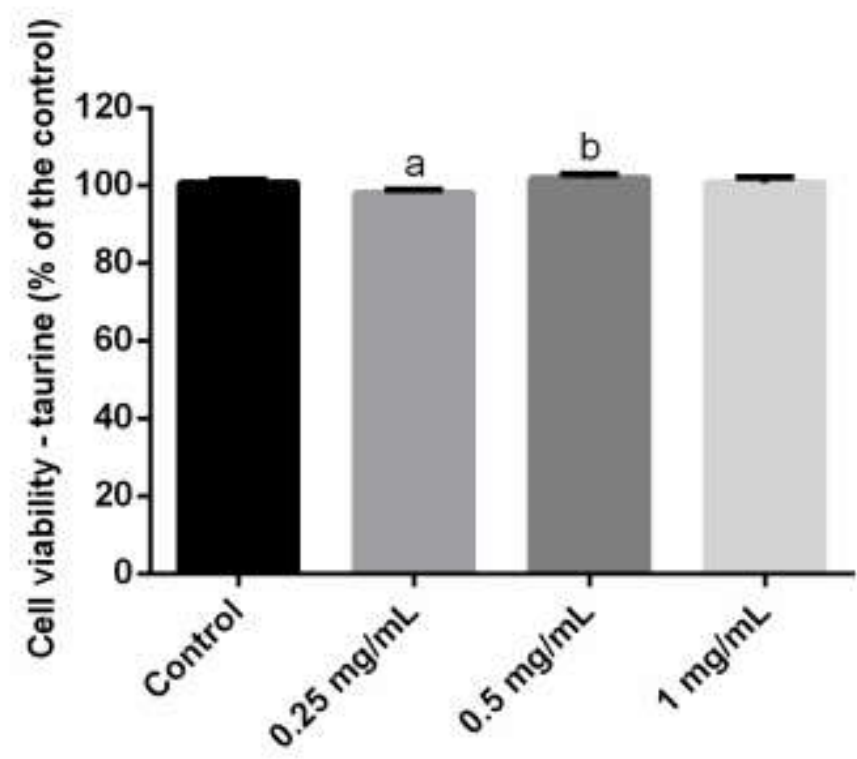

Source: GraphPad Prism 6.0.

As observed in figure 3, cells exposed to $100 \mu \mathrm{M}$ hydrocortisone were as viable as the control group (no statistical difference between them). However, $50 \mu \mathrm{M}$ hydrocortisone statistically increased cell viability $(\mathrm{p}=0.0051)$ compared to the control group (c), and 150 and $200 \mu \mathrm{M}$ hydrocortisone significantly reduced cell viability ( $\mathrm{p}<0.0001$ ), both compared to control group (d, e) (Figure 3). 
Figure 3. SH-SY5Y viability on different concentrations of hydrocortisone (50;100; 150 and $200 \mu \mathrm{M}$, respectively).

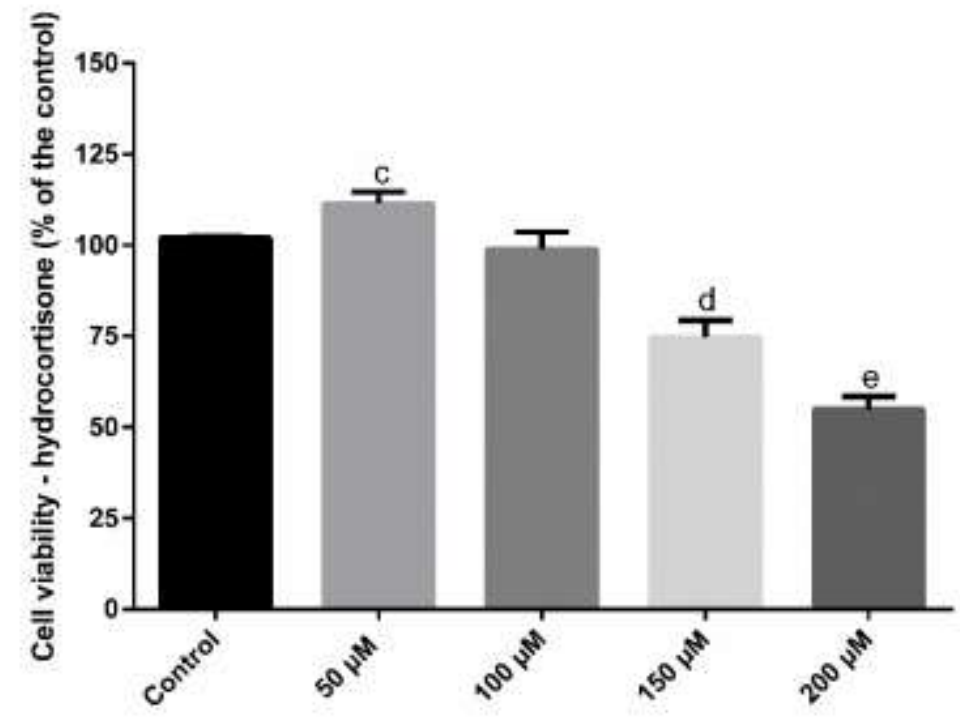

Source: GraphPad Prism 6.0.

As shown in figure 4 , taurine $(0.5 \mathrm{mg} / \mathrm{mL}$ ) increased cell viability ( $\mathrm{p}=0.0457)$ compared to the control group (f). However, when cells are exposed to $200 \mu \mathrm{M}$ hydrocortisone, it is clearly observed a decrease in cell viability ( $\mathrm{p}<0.0001)$ compared to the control group (g), demonstrating the oxidative stress caused by it. Curiously, pretreating cells with taurine and then exposing them to hydrocortisone not only preserved but also statistically increased cells viability, compared to the control group $(\mathrm{h})(\mathrm{p}<0.0001)$, demonstrating the protective effect of taurine against hydrocortisone. Moreover, taurine $(0.5 \mathrm{mg} / \mathrm{mL}) \mathrm{w}$ as also statistically different from the hydrocortisone $(@)$ ( $\mathrm{p}<0.0001)$ and the pretreatment $(\#)$ (p <0.0001) groups. Finally, the pretreatment group showed a significant increase in cell viability comparing to the hydrocortisone group $(\$)(\mathrm{p}<0.0001)($ Figure 4).

Figure 4. SH-SY5Y viability on taurine $(0.5 \mathrm{mg} / \mathrm{mL})$, hydrocortisone $(200 \mu \mathrm{M})$ and taurine $(0.5 \mathrm{mg} / \mathrm{mL})$ pretreatment followed by hydrocortisone $(200 \mu \mathrm{M})$ as stressor agent.

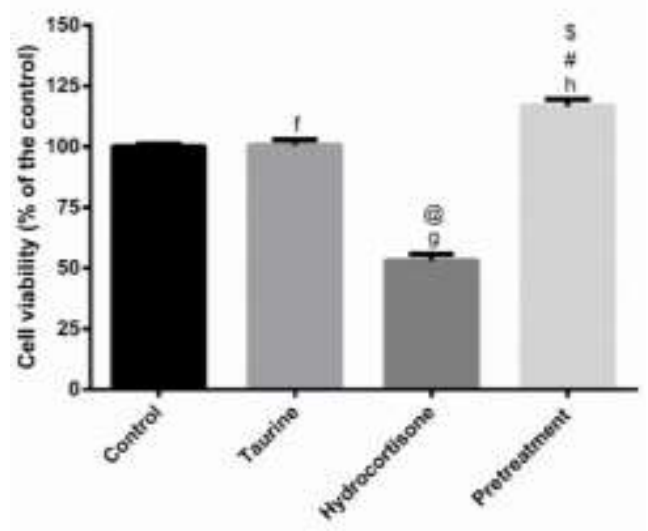

Source: GraphPad Prism 6.0. 


\section{Cell morphology analysis}

In Figure 5, cell membrane of the control and taurine groups is widely spread, a considerable characteristic of neuroblastoma cells. However, when cells are exposed only to the stressor agent, hydrocortisone, their projections are not observed, and cells demonstrate a retracted and rounded shape (white arrows indicate cellular projections). Curiously, cells of the pretreatment group, which were incubated with taurine and hydrocortisone, respectively, demonstrate preserved membrane projections and morphological aspect, representing the protective effect of the pretreatment against the stressor agent (Figure 5).

Figure 5. SEM images of the groups: Control, Taurine, Hydrocortisone and Pretreatment.

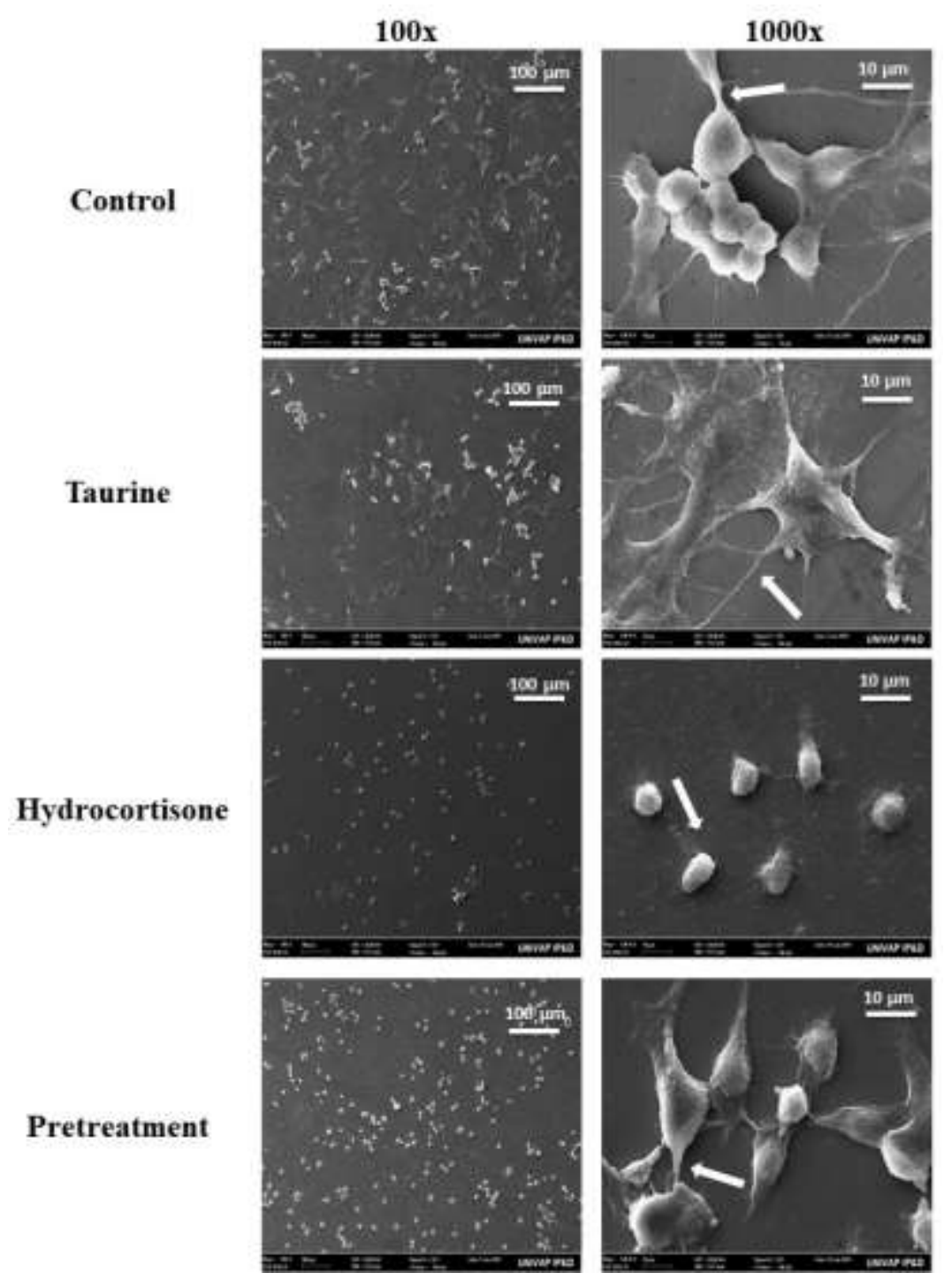

Source: Authors.

The frequency of membrane projection in the neural cell line SH-SY5Y was counted using the micrographs obtained by SEM and represented in Figure 6. An increase in the number of cells with projections is statistically observed in the taurine group compared to the control (i) ( $\mathrm{p}<0.0001$ ). In the group exposed to hydrocortisone, there was a statistical decrease in cells with projections compared to the control group (j) ( $<<0.0001)$. When comparing taurine group $(0.5 \mathrm{mg} / \mathrm{mL})$ with hydrocortisone and pretreatment group, statistical difference was also observed $(\&, \mathrm{p}<0.0001)$ and $(*, \mathrm{p}<0.0001)$, respectively. Finally, the 
pretreatment group showed a significant increase in the frequency of neural cell extensions compared to the hydrocortisone group $(\S)(\mathrm{p}<0.0001)$. There was no statistical difference between the control and pretreatment groups.

Figure 6. SH-SY5Y projections within the groups: Control, Taurine, Hydrocortisone and Pretreatment.

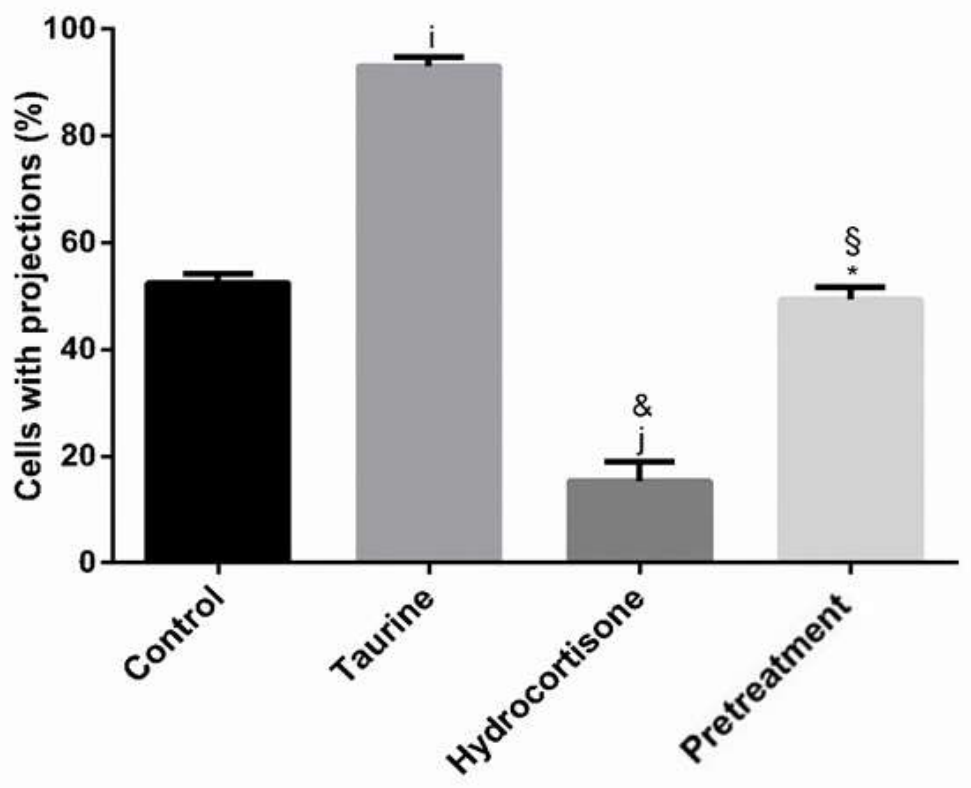

Source: GraphPad Prism 6.0.

\section{Discussion}

Among the achievement of this study, it is proposed here a considerable stressor model for neural cells, using hydrocortisone, an analogue of cortisol, for metabolic and oxidative stress, which are commonly associated to AD and other neurodegenerative disorders. Thus, this study establishes a potential in vitro model for AD to further investigate the neural effects of systemic oxidative damage and the metabolic dysregulation provided by the hormone cortisol. Also, herein, taurine is shown to be a promising alternative against the stress led by hydrocortisone, promoting neuroprotection in cells subjected to stress, as verified in the cell viability assays, in the morphological aspects preserved and in the cellular projections maintained when cells are pretreated with taurine and then exposed to hydrocortisone.

First, when conducting the study in the hydrocortisone group (a commercial drug with similar function to the cortisol hormone), it is seen cellular response in a dose-dependent manner. This event corroborates Fonseca; Da Silva; Soares, 2019, which established positive effects of hydrocortisone in the organism in low concentration since it maintains glucose metabolism. In parallel, it is essential to consider that, at higher concentrations, cortisol may reduce cell viability, which was evidenced by De La Rubia Ortí et al., 2017 with neural and brain damage and a reduction in the synapse in nervous tissue, corroborating this study. Toledo et al., 2012 observed that high concentrations of cortisol alter the composition of cerebrospinal fluid, along with experimental evidence of damage to the hippocampus. Moreover, Curto et al., 2017 highlighted that increased plasma cortisol levels can be associated with the progression of cognitive deficit. The metabolic stress, related to high concentrations of cortisol, causes oxidative stress, thus enabling the appearance and acceleration of the clinical picture of neurodegenerative diseases.

To prevent the consequences of metabolic and oxidative stress resulting from high cortisol concentrations, supplementation with taurine is a key factor, increasing cell viability and promoting neuroprotection, as evidenced in this study. 
According to Sartori, 2015, nutritional supplementation with taurine contributes to the immune system's increased response since it acts on cellular osmoregulation and protein stabilization in cardiac and neural cells. Ripps; Shen, 2012 highlighted that taurine has an important neural role due to its cytoprotective capacity, which helps control salt concentrations, consequently improving cellular metabolic activity and antioxidation and cell development. Besides, Conrado et al., 2017 demonstrated that taurine improves the central nervous system, thereby exercising a neurotransmitter function and improving the synapse. These results agree with Panda; Mishra; Mishra, 2018, who reported the taurine ability to minimize oxidative stress, which acts in the control of salt concentrations in cells and the stabilization of cell membrane.

The metabolic and oxidative stress effect of hydrocortisone was confirmed morphologically by SEM, which corroborates the results of cell viability. The micrographs were obtained at 100-fold increase, permitting the observation of cell population, and at 1000-fold increase, to observe individual cell morphology and projection in each evaluated group. So, in the hydrocortisone group, there was a structural change in the cytoskeleton, resulting of the stimulated stress, consequently retracting neural cells characteristic projections. Inelia Morales; Gonzalo Faras; Ricardo, 2010 associated these structural changes to oxidative stress, stating that ROSs causes metabolic stress. When ROS is produced in excess in our body, it can lead to structural changes in proteins, lipids, and nucleic acids, leading to cell death. Baker-Nigh et al., 2015 described the effect of oxidative stress on the cholinergic system, a fact presented as specific characteristics and vital importance for AD's progression. Since cholinergic neurons are particularly vulnerable to oxidative and metabolic stress, it causes damage to cholinergic signaling and, consequently, changes in neural morphology and its mechanisms.

Wei; Ji, 2018 observed a reduction in the number of nerve cells and the connections between them, and correlated it with the progressive reduction in brain volume, it was also confirmed by De Falco et al., 2016, who verified the association between oxidative stress and the proliferation of astrocytes and activation of microglia, in order to justify the inflammatory mechanism of AD. Together with the metabolic stress caused by cortisol, these changes can aggravate AD's chronicity. Salameh et al., 2015 observed that glycemic oscillations can cause insulin resistance and metabolic alteration, as well as changes in the function of the insulin receptor and changes in the pattern of the vascular structure about the endothelial cells, in addition to an increase in astrocytes, cells which make up the BHE. According to (Ruiz et al., 2016) causes signaling changes and in the growth factor that keep nerve cells healthy, which can disrupt glucose metabolism. In addition to being related to changes in the metabolism of beta-amyloid protein, as a result, it presents evidence of the close relationship between the pathways of the brain insulin receptors with the accumulation of beta-amyloid protein and the abnormal and hyperphosphorylated tau protein, oxidative stress, and metabolic. Our results agree with (Salles et al., 2018), which showed that oxidative stress causes morphological changes, loss of interaction and neural function, critical cellular events that can trigger neural cell death signaling. Lee et al., 2017 corroborates the observation of neural failure in AD, thereby establishing a correlation between metabolic and oxidative stress caused in neural cells.

At the same time, it is possible to verify the neuroprotective effect of taurine by SEM robust with cell viability results morphologically. Thus, it can be observed that taurine preserved the cytoskeleton and maintained the characteristic neural cell extensions and the spatial structure. According to Tyagi et al., 2015, this may be related to supplementation, thus increasing the expression of BDNF, thereby improving the function of the ion channel receptor, production of secondary messengers, and enzymatic activity, signal transmission, gene expression, and secretion of neurotransmitters. This way, it results in neural remodeling, which improved cell morphology since it maintained the neural cells' projections ramifications.

Consequently, the neural cell shows an improvement in the response against ROSs, confirmed by Ripps; Shen, 2012, that emphasized taurine's thrilling action as a promoter of cellular homeostasis and its role in improving mitochondrial function, which is in agreement with Panda; Mishra; Mishra, 2018. According to Shimada, K., 2015, the anti-inflammatory property of taurine can stimulate the nervous system and attenuate cellular senescence. The cytoprotective action of taurine is also affirmed 
by Wang et al., 2018, who mentioned that the substance leads to metabolic improvement of neural cell, contributing with the development of DNA and preventing cell apoptosis. It occurs, according to Freitas, 2016, due to the ability of taurine to facilitate cell permeability, thereby preventing formation and damage resulting from ROSs, in addition to functioning as a buffer that maintains the $\mathrm{pH}$ of the medium and captures electrically viable ions.

However, according to Corrêa et al., 2015, cortisol is a steroid-related to metabolic and cellular stress. Thus, Corrêa et al., 2016 suggest that cortisol is a reliable marker for cognitive changes. Zvěřová et al., 2013 showed that cortisol increases are related to patients' cognitive decline. Wang et al., 2018 reported the improved response capacity of the hypothalamic adrenocortical axis (HPA) to noradrenergic stimulatory regulation in $\mathrm{AD}$, as well as the rupture of the blood-brain barrier, contribute to the clinical picture since the noradrenergic stimulatory regulation of the brainstem of the HPA axis, are substantially increased in AD.

The analysis of neurites projections with the stressor agent hydrocortisone provides oxidative damage and, consequently, metabolic stress to the neural cell. According to Reitz; Mayeux, 2014, the reduction in neurites density accompanies the decrease in cell viability in a dose-dependent manner to oxidative and consequently metabolic stress. It corroborates Jack; Holtzman, 2013, which indicated that hyperphosphorylation of tau and its subsequent deposition is related to the degeneration of neurons in AD patients' brains and the decrease in prolongations which can be used as an essential biomarker for this disease pathology. According to Kawahara, 2012, it is related to the beta-amyloid aggregates, thereby showing the calcium channels' responsibility in the cell membrane and allowing the ion to enter. These events can destabilize homeostasis and modify the characteristic morphology of the neural cell. These biochemical and morphological changes can culminate in progressive cell death, a considerable characteristic of AD.

Interestingly, we demonstrate that the supplementation with taurine reversed this scenario, corroborating Hansen et al., 2010, the neural differentiation of SH-SY5Y cells and phenotypic changes, such as emission of cytoplasmic projections, reduction of proliferation, expression of dopaminergic markers. According to Gnegy, 2012, all this may be related to stimulation of tropomyosin kinase B's expression (TrkB) receptor, which makes cells responsive to the brain-derived neurotrophic factor (BDNF), thus serving as a growth factor for neural cells. The differentiation of mature neuronal phenotypes under the right conditions is emphasized, resulting in more extensions and branched neurites.

\section{Conclusion}

This study proposed an in vitro model of neural stress, caused by a specific concentration of hydrocortisone $(200 \mu \mathrm{M})$, representing a valuable tool to further elucidate aspects of $\mathrm{AD}$ and other neurodegenerative diseases. Importantly, we also demonstrated for the first time that taurine can be cytoprotective for human neural cells, specially protecting them against the metabolic stressor effects of hydrocortisone.

$\mathrm{AD}$ is a neurodegenerative disorder characterized by cognitive decline that eventually leads to death. Oxidative stress facilitates some of the damage caused by beta amyloid and stimulates its formation inside the brain. Excitingly, our results really show that it is possible to prevent the oxidative stress. Despite needing further studies, we believe that the use of taurine representes a promising therapeutic strategy to be combined with well established conventional treatments already available, specially for early stages of the disease.

Based on the results demonstrated in this study, we intend to further explore the use of taurine reversing the oxidative stress caused by hydrocortisone in induced pluripotent stem cells (IPSC) developed from biopsies of patients diagnosed with $\mathrm{AD}$, evaluating the increase or decrease of the presence of amyloid oligomers and hyperphosphorylated tau protein outside and inside the cells, respectively. 


\section{Acknowledgments}

This study was financially supported by the Coordination for the Improvement of Higher Education Personnel (CAPES) and São Paulo Research Foundation FAPESP (grant 2016/17984-1). We would like to thank our advisor Dr. Cristina Pacheco Soares, from the cell dynamics and compartment laboratory, where this research was developed.

\section{References}

Baker-Nigh, A., Vahedi, S., Davis, E. G., Weintraub, S., Bigio, E. H., Klein, W. L., \& Geula, C. (2015). Neuronal amyloid- $\beta$ accumulation within cholinergic basal forebrain in ageing and Alzheimer's disease. Brain, 138(6), 1722-1737. https://doi.org/10.1093/brain/awv024

Barbosa, M. G. A. et. al. (2020). The use of Canabidiol compound in the treatment of Alzheimer's disease(literature review). Journal of Chemical Information and Modeling, 53(9), 1689-1699.

Belyaev, N. D., Kellett, K. A. B., Beckett, C., Makova, N. Z., Revett, T. J., Nalivaeva, N. N., Hooper, N. M., \& Turner, A. J. (2010). The transcriptionally active amyloid precursor protein (APP) intracellular domain is preferentially produced from the 695 isoform of APP in a $\beta$-secretase-dependent pathway. Journal of Biological Chemistry, 285(53), 41443-41454. https://doi.org/10.1074/jbc.M110.141390

Conrado, A. B., Maina, S., Moseley, H., Francioso, A., Mosca, L., Capuozzo, E., \& Fontana, M. (2017). Neuroprotective Effect of Taurine-Rich Cuttlefish (Sepia officinalis) Extract Against Hydrogen Peroxide-Induced Oxidative Stress in SH-SY5Y Cells. 975, 551-561. https://doi.org/10.1007/978-94-024-1079-2

Corrêa, M. S., Vedovelli, K., Giacobbo, B. L., de Souza, C. E. B., Ferrari, P., de Lima Argimon, I. I., Walz, J. C., Kapczinski, F., \& Bromberg, E. (2015). Psychophysiological correlates of cognitive deficits in family caregivers of patients with Alzheimer Disease. Neuroscience, 286, 371-382. https://doi.org/10.1016/j.neuroscience.2014.11.052

Corrêa, Márcio Silveira, Giacobbo, B. L., Vedovelli, K., De Lima, D. B., Ferrari, P., De Lima Argimon, I. I., CesarWalz, J., \& Bromberg, E. (2016). Age effects on cognitive and physiological parameters in familial caregivers of Alzheimer's disease patients. PLoS ONE, 11(10), 1-16. https://doi.org/10.1371/journal.pone.0162619

Curto, M., Martocchia, A., Ferracuti, S., Comite, F., Scaccianoce, S., Girardi, P., Nicoletti, F., \& Falaschi, P. (2017). Increased Total Urinary Cortisol (tUC) and Serum Brain-derived Neurotrophic Factor (BDNF) Ratio in Alzheimer Disease (AD)-affected Patients. Alzheimer Disease and Associated Disorders, 31(2), 173-176. https://doi.org/10.1097/WAD.0000000000000156

Dailton Guedes de Oliveira Moraes, C., Henrique Godoi, B., Chaves Silva Carvalho, I., Cristina Pinto, J., Carvalho Rossato, R., Soares da Silva, N., \& Pacheco Soares, C. (2019). Genotoxic effects of photodynamic therapy in laryngeal cancer cells - An in vitro study. Experimental Biology and Medicine, 244(3), 262271. https://doi.org/10.1177/1535370219826544

Falco, A., Cukierman, D. S., Hauser-Davis, R. A., \& Rey, N. A. (2016). Doença de Alzheimer: Hipóteses etiológicas e perspectivas de tratamento. Quimica Nova, 39(1), 63-80. https://doi.org/10.5935/0100-4042.20150152

La Rubia Ortí, J. E., Castillo, S. S., Benlloch, M., Rochina, M. J., Arreche, S. C., \& García-Pardo, M. P. (2017). Impact of the relationship of stress and the immune system in the appearance of Alzheimer's disease. Journal of Alzheimer's Disease, 55(3), 899-903. https://doi.org/10.3233/JAD-160903

Gnegy, M. E. (2012). Catecholamines. Basic Neurochemistry, 283-299. https://doi.org/10.1016/B978-0-12-374947-5.00014-6

Grothe, M. J., Schuster, C., Bauer, F., Prudlo, J., Teipel, S. J., \& Heinsen, H. (2014). Atrophy of the cholinergic basal forebrain in dementia with lewy bodies and alzheimer's disease dementia. Journal of Neurology, 261(1), 1939-1948. https://doi.org/10.1007/s00415-014-7439-z

Hansen, S. H., Andersen, M. L., Cornett, C., Gradinaru, R., \& Grunnet, N. (2010). A role for taurine in mitochondrial function. Journal of Biomedical Science, 17(SUPPL. 1), 1-8. https://doi.org/10.1186/1423-0127-17-S1-S23

Inelia Morales, G., Gonzalo Faŕas, G., \& Ricardo, B. (2010). La neuroinfamacín como factor detonante del desarrollo de la enfermedad de Alzheimer. Revista Chilena de Neuro-Psiquiatria, 48(1), 49-57. https://doi.org/10.4067/s0717-92272010000200007

Jack, C. R., \& Holtzman, D. M. (2013). Biomarker modeling of alzheimer's disease. Neuron, 80(6), 1347-1358. https://doi.org/10.1016/j.neuron.2013.12.003 Jeanneteau, F., \& Chao, M. V. (2013). Are BDNF and glucocorticoid activities calibrated? Neuroscience, 239, 173-195. https://doi.org/10.1016/j.neuroscience.2012.09.017

Kawahara, M. (2012). Neurotoxicity of $\beta$-Amyloid-Amyloid Protein: Oligomerization, Channel Formation and Calcium Dyshomeostasis. Current Pharmaceutical Design, 16(25), 2779-2789. https://doi.org/10.2174/138161210793176545

Kilb, W., \& Fukuda, A. (2017). Taurine as an Essential Neuromodulator during Perinatal Cortical Development. Frontiers in Cellular Neuroscience, 11(October), 1-13. https://doi.org/10.3389/fncel.2017.00328

Lee, Y., Ham, S., Lee, Y. Il, Jo, M., Kim, H., Kang, H., Jo, A., Lee, G. H., Mo, Y. J., Park, S. C., Lee, Y. S., \& Shin, J. H. (2017). Hydrocortisone-induced parkin prevents dopaminergic cell death via CREB pathway in Parkinson's disease model. Scientific Reports, 7(1), 1-13. https://doi.org/10.1038/s41598-01700614-w

Liu, C. C., Kanekiyo, T., Xu, H., \& Bu, G. (2013). Apolipoprotein e and Alzheimer disease: Risk, mechanisms and therapy. Nature Reviews Neurology, 9(2), 106-118. https://doi.org/10.1038/nrneurol.2012.263 
Marcinkiewicz, J., \& Kontny, E. (2014). Taurine and inflammatory diseases. Amino Acids, 46(1), 7-20. https://doi.org/10.1007/s00726-012-1361-4

McEwen, B. S. (2013). Erratum: Brain on stress: How the social environment gets under the skin (Proceedings of the National Academy of Sciences of the United States of America (2012) 109 (17180-17185) DOI: 10.1073/pnas.1121254109). Proceedings of the National Academy of Sciences of the United States of America, 110(4), 1561. https://doi.org/10.1073/pnas.1221399110

Nelson, P. T., Alafuzoff, I., Bigio, E. H., Bouras, C., Braak, H., Cairns, N. J., Castellani, R. J., Crain, B. J., Davies, P., Tredici, K. Del, Duyckaerts, C., Frosch, M. P., Haroutunian, V., Hof, P. R., Hulette, C. M., Hyman, B. T., Iwatsubo, T., Jellinger, K. A., Jicha, G. A., ... Beach, T. G. (2012). Correlation of alzheimer disease neuropathologic changes with cognitive status: A review of the literature. Journal of Neuropathology and Experimental Neurology, 71(5), 362-381. https://doi.org/10.1097/NEN.0b013e31825018f7

Oliveira Fonseca, M., Da Silva, N. S., \& Soares, C. P. (2019). Effect of cortisol on K562 leukemia cells. Mundo da Saude, 43(4), 854-869. https://doi.org/10.15343/0104-7809.20194304854869

Panda, S., Mishra, S. R., \& Mishra, V. V. V. (2018). A Review On " Taurine-a Magic Molecule ". European Journal of Pharmaceutical and Medical Research, 5(02), 534-536.

Reitz, C., \& Mayeux, R. (2014). Alzheimer disease: Epidemiology, diagnostic criteria, risk factors and biomarkers. Biochemical Pharmacology, 88(4), 640651. https://doi.org/10.1016/j.bcp.2013.12.024

Ripps, H., \& Shen, W. (2012). Review: Taurine: A “very essential” amino acid. Molecular Vision, 18(November), $2673-2686$.

Rossato, R. C. (2019). Hydrocortisone cytorestores oxidative stress-induced neuroblastoma. Alzheimer's \& Dementia, 15, P642-P642.

Ruiz, H. H., Chi, T., Shin, A. C., Lindtner, C., Hsieh, W., Ehrlich, M., Gandy, S., \& Buettner, C. (2016). Increased susceptibility to metabolic dysregulation in a mouse model of Alzheimer's disease is associated with impaired hypothalamic insulin signaling and elevated BCAA levels. Alzheimer's and Dementia, 12(8), 851-861. https://doi.org/10.1016/j.jalz.2016.01.008

Salameh, T. S., Bullock, K. M., Hujoel, I. A., Niehoff, M. L., Wolden-Hanson, T., Kim, J., Morley, J. E., Farr, S. A., \& Banks, W. A. (2015). Central Nervous System Delivery of Intranasal Insulin: Mechanisms of Uptake and Effects on Cognition. Journal of Alzheimer's Disease, 47(3), 715-728. https://doi.org/10.3233/JAD-150307

Salles, G. N., Calió, M. L., Afewerki, S., Pacheco-Soares, C., Porcionatto, M., Hölscher, C., \& Lobo, A. O. (2018). Prolonged Drug-Releasing Fibers Attenuate Alzheimer's Disease-like Pathogenesis. ACS Applied Materials and Interfaces, 10(43), 36693-36702. https://doi.org/10.1021/acsami.8b12649

Salles, G. N., Pereira, F. A. dos S., Pacheco-Soares, C., Marciano, F. R., Hölscher, C., Webster, T. J., \& Lobo, A. O. (2017). A Novel Bioresorbable Device as a Controlled Release System for Protecting Cells from Oxidative Stress from Alzheimer's Disease. Molecular Neurobiology, 54(9), 6827-6838. https://doi.org/10.1007/s12035-016-0200-0

Sartori, T. (2015). Sartori, T. Efeitos da glutamina e taurina sobre a via de sinalização do NF $\kappa$ B em células Raw 264 . 7 estimuladas com LPS Talita Sartori. 2015 .

Shimada, K., et al. (2015). Observation: Application and advantages of BMK in osteoporosis by monitoring the dose of antiresorptive drugs with CTx. Journal of the Medical Association of Thailand, 94(10 SUPPL.), 581-596. https://doi.org/10.1007/978-3-319-15126-7

Toledo, J. B., Toledo, E., Weiner, M. W., Jack, C. R., Jagust, W., Lee, V. M. Y., Shaw, L. M., \& Trojanowski, J. Q. (2012). Cardiovascular risk factors, cortisol, and amyloid- $\beta$ deposition in Alzheimer's Disease Neuroimaging Initiative. Alzheimer's and Dementia, 8(6), 483-489. https://doi.org/10.1016/j.jalz.2011.08.008

Tyagi, E., Zhuang, Y., Agrawal, R., Ying, Z., \& Gomez-Pinilla, F. (2015). Interactive actions of Bdnf methylation and cell metabolism for building neural resilience under the influence of diet. Neurobiology of Disease, 73, 307-318. https://doi.org/10.1016/j.nbd.2014.09.014

Vitaliano, P. P., Murphy, M., Young, H. M., Echeverria, D., \& Borson, S. (2011). Does caring for a spouse with dementia promote cognitive decline? A hypothesis and proposed mechanisms. Journal of the American Geriatrics Society, 59(5), 900-908. https://doi.org/10.1111/j.1532-5415.2011.03368.x

Wang, L. Y., Raskind, M. A., Wilkinson, C. W., Shofer, J. B., Sikkema, C., Szot, P., Quinn, J. F., Galasko, D. R., \& Peskind, E. R. (2018). Associations between CSF cortisol and CSF norepinephrine in cognitively normal controls and patients with amnestic MCI and AD dementia. International Journal of Geriatric Psychiatry, 33(5), 763-768. https://doi.org/10.1002/gps.4856

Wei, W., \& Ji, S. (2018). Cellular senescence: Molecular mechanisms and pathogenicity. Journal of Cellular Physiology, 233(12), 9121-9135. https://doi.org/10.1002/jcp.26956

Zhou, Y., Holmseth, S., Guo, C., Hassel, B., Höfner, G., Huitfeldt, H. S., Wanner, K. T., \& Danbolt, N. C. (2012). Deletion of the $\gamma$-aminobutyric acid transporter 2 (GAT2 and SLC6A13) gene in mice leads to changes in liver and brain taurine contents. Journal of Biological Chemistry, 287(42), 35733-35746. https://doi.org/10.1074/jbc.M112.368175

Zvěřová, M., Fišar, Z., Jirák, R., Kitzlerová, E., Hroudová, J., \& Raboch, J. (2013). Plasma cortisol in Alzheimer’s disease with or without depressive symptoms. Medical Science Monitor, 19(1), 681-689. https://doi.org/10.12659/MSM.889110 